\title{
Pembelajaran Geometri Berbasis Geogebra Sebagai Upaya Meningkatkan Kemampuan Komunikasi Matematis
}

\author{
Nanang Supriadi \\ IAIN Raden Intan Lampung; nanangsupriadi@gmail.com
}

Submitted : 13-08-2015, Revised : 20-11-2015, Accepted : 16-12-2015

\begin{abstract}
Geometry as one of the areas of study in school math materials receives a large portion for students to study at school. From distribution distribution of competency standard for junior high education unit, geometry material get the biggest portion (41\%) compared to other material such as algebra (29\%), number (18\%), and statistics and opportunity (12\%). Nevertheless, the mastery of students in understanding the concept of geometry is still low and needs to be improved. Teaching geometry in schools is expected to provide a systematic attitude and habits for students to be able to give an idea of the relationships between geometry builds and categorizations between the builds, so that in the learning of geometry students can visualize, describe, And comparing wake-up geometry in various positions, so that students can understand it needed a computer-based learning model of dynamic geometry software GeoGebra software. With the help of this software the students better understand the concepts in geometry. Considerations on the use of dynamic geometry software such as GeoGebra in mathematics learning, especially geometry, allow students to be active in building understanding of geometry. GeoGebra based geometry learning on the learning process proved to significantly improve students' mathematical communication skills, it was critical and creative attitude during the student's learning. Improved mathematical communication skills of students who received geoGebra-based geometry learning are in the medium category. This indicates that students have improved mathematical communication ability better than previous results.
\end{abstract}

Keyword: GeoGebra; Geometric; Communication.

\begin{abstract}
Abstrak
Geometri sebagai salah satu bidang kajian dalam materi matematika sekolah memperoleh porsi yang besar untuk dipelajari oleh siswa di sekolah. Dari distribusi penyebaran standar kompetensi untuk satuan pendidikan SMP, materi geometri mendapatkan porsi yang paling besar (41\%) dibandingkan dengan materi lain seperti aljabar (29\%), bilangan (18\%), serta statistika dan peluang (12\%). Namun demikian, penguasaan siswa dalam memahami konsep geometri masih rendah dan perlu ditingkatkan. Pengajaran geometri di sekolah diharapkan memberikan suatu sikap dan kebiasaan sistematik bagi siswa untuk bisa memberikan gambaran tentang hubungan-hubungan di antara bangun-bangun geometri serta penggolongan-penggolongan di antara bangun-bangun tersebut, untuk itu agar dalam pembelajaran geometri siswa dapat memvisualisasikan, menggambarkan, serta memperbandingkan bangun-bangun geometri dalam berbagai posisi, sehingga siswa dapat memahaminya dibutuhkan sebuah model pembelajaran berbasis software komputer
\end{abstract}


dynamic geometry software yaitu GeoGebra. Dengan bantuan software ini siswa lebih memahami konsep-konsep dalam geometri. Pertimbangan tentang penggunaan dynamic geometry software seperti GeoGebra dalam pembelajaran matematika, khususnya geometri, diantaranya memungkinkan siswa untuk aktif dalam membangun pemahaman geometri. Pembelajaran geometri berbasis GeoGebra pada proses pembelajaran terbukti secara signifikan dapat meningkatkan kemampuan komunikasi matematis siswa, selaian itu sikap kritis dan kreatif selama pembelajaran ditunjukkan siswa. Peningkatan kemampuan komunikasi matematis siswa yang mendapat pembelajaran geometri berbasis GeoGebra berada pada kategori sedang. Hal ini menunjukkan bahwa siswa telah mengalami peningkatan kemampuan komunikasi matematis lebih baik dibandingkan hasil sebelumnya.

Kata Kunci: GeoGebra; Geometris; Komunikasi.

\section{PENDAHULUAN}

Badan Standar Nasional Pendidikan (BSNP) telah menetapkan tujuan umum pembelajaran matematika yang tertuang dalam Permendiknas No. 22 Tahun 2006, yakni kemampuan untuk memahami, menjelaskan keterkaitan, mengaplikasikan konsep matematika secara luwes, akurat, efisien, dan tepat dalam pemecahan masalah; menggunakan penalaran pada pola dan sifat, melakukan manipulasi matematika dalam membuat generalisasi, menyusun bukti, atau menjelaskan gagasan dan pernyataan matematika; memecahkan masalah yang meliputi kemampuan memahami masalah, merancang model matematika, menyelesaikan model, dan menafsirkan solusi yang diperoleh; mengkomunikasikan gagasan dengan simbol, tabel, diagram, atau media lain untuk memperjelas keadaan atau masalah; memiliki sikap menghargai kegunaan matematika dalam kehidupan, yaitu rasa ingin tahu, perhatian, dan minat dalam mempelajari matematika, serta sikap ulet dan percaya diri dalam pemecahan masalah.

Merujuk tujuan pembelajaran matematika di atas, kemampuan komunikasi matematis penting untuk diperhatikan, melalui komunikasi matematis siswa dapat mengorganisasi dan mengkonsolidasi berpikir matematisnya baik secara lisan maupun tulisan yang dapat terjadi dalam proses pembelajaran. Hasil observasi penulis juga memperlihatkan masih rendahnya kemampuan siswa dalam mengkomunikasikan situasi, ide atau gagasan ke dalam model atau bahasa matematika baik secara lisan maupun tulisan yang merupakan indikator dari kemampuan komunikasi matematis siswa. Menurut hemat penulis, hal tersebut disebabkan oleh dua faktor yaitu pembelajaran yang dilakukan kurang dapat mengakomodir kemampuan komunikasi matematis siswa dan soal-soal yang diberikan masih merupakan soal-soal yang rutin dengan kata lain kurang memfasilitasi High-Order Mathematical Thinking siswa. Kondisi tersebut diperkuat oleh Tandililing (2011) yang menyatakan bahwa tingkat komunikasi matematis siswa SMP yang menggunakan pembelajaran biasa cenderung rendah.

Materi matematika yang memiliki karakteristik tersebut yaitu geometri. Geometri sebagai salah satu bidang kajian dalam materi matematika sekolah memperoleh porsi yang besar untuk dipelajari oleh siswa di sekolah. Menurut Siregar, N. (2011) dari distribusi penyebaran standar kompetensi untuk satuan pendidikan SMP, materi geometri mendapatkan porsi yang paling besar (41\%) dibandingkan dengan materi lain seperti aljabar (29\%), bilangan (18\%), serta statistika dan peluang (12\%). (Laborde et al dalam Nurhasanah, 2010) mengungkapkan bahwa hal tersebut bahkan terjadi di level internasional sekalipun. Jiang (2008) menuturkan bahwa bagian dari matematika yang lemah diserap dan pengetahuan serta pengalaman yang terbatas dimiliki oleh siswa adalah geometri. 
Solusi agar pembelajaran matematika khususnya materi geometri lebih baik dari sebelumnya adalah dengan menggunakan model pembelajaran berbasis software computer dynamic geometrysoftware yaitu GeoGebra. Dengan bantuan software ini diharapkan siswa lebih memahami konsep-konsep dalam geometri. Wees (Rahman, 2010) mengatakan bahwa pertimbangan dalam penggunaan dynamic geometry software seperti GeoGebra khususnya geometri, adalah memungkinkan siswa untuk terlibat aktif dalam meningkatkan pemahaman geometri.

GeoGebra memungkinkan siswa terlibat penuh dalam menvisualisasikan secara sederhana dari konsep geometris yang rumit. Selain itu Putz (Rahman, 2010) mengemukanan ketika siswa menggunakan GeoGebra, pemahaman siswa akan lebih mendalam. Visualisasi dalam GeoGebra yang ditampilkan secara menarik, dapat digerakkan dan diubah bentuk serta ukurannya, memberi kesempatan kepada siswa untuk melakukan eksplorasi dan observasi dengan mudah. Eksplorasi sangat diperlukan ketika siswa berusaha memahami suatu konsep atau membangun pengetahuan. Eksplorasi dan observasi dengan bantuan komputer dalam pembelajaran matematika sangat penting dilakukan guna mengembangkan kemampuan komunikasi matematis siswa, maka dalam penelitian ini peneliti menjadikan komputer sebagai alat utama dalam mengembangkan kemampuan tersebut.

\section{METODE PENELITIAN}

Penelitian ini merupakan penelitian kuasi eksperimen karena adanya manipulasi perlakuan serta pengambilan sampel dilakukan terhadap kelompok-kelompok yang sudah jadi. Adapun desain penelitian yang digunakan adalah nonequivalent groups pretest-posttest design. Desain ini dipilih karena peneliti beranggapan bahwa subjek tidak dikelompokkan secara acak, tetapi peneliti menerima keadaan subjek seadanya. Pada penelitian ini juga terdapat pretest, perlakuan (treatment), dan posttest. Berikut ini disajikan desain penelitian one group pretest-posttest.

$\begin{array}{lll}\text { Pretest } & \text { Treatment } & \text { Posttest } \\ 0 & X & 0\end{array}$

Keterangan:

O : Pretest atau Posttest

$X \quad$ : Pembelajaran geometri berbasis GeoGebra.

Pembelajaran yang didesain oleh penulis memungkinkan untuk dilakukannya tindakan pembelajaran yang dapat terlaksana dengan maksimal. Instrumen penelitian ini berbentuk tes, tes kemampuan komunikasi matematis merupakan tes kemampuan berpikir yang berfungsi untuk mengungkap kemampuan komunikasi matematis yang dimiliki siswa dalam berbagai permasalahan. Tes kemampuan komunikasi matematis, berbentuk tes uraian yang terdiri dari 6 soal. Data yang diperoleh dari skor hasil tes awal kemampuan komunikasi matematis dibandingkan skor total dari tiap siswa pada skor tes akhir. Tingkat signifikansi peningkatan kemampuan komunikasi matematis setelah siswa menggunakan pembelajaran geometris berbasis GeoGebra diuji dengan menggunakan statistik uji t. 
HASIL ANALISIS DATA

Deskripsi Peningkatan Kemampuan Komunikasi Matematis siswa

Deskripsi skor peningkatan kemampuan komunikasi matematis merupakan gambaran peningkatan kemampuan komunikasi matematis siswa setelah melaksanakan tes awal dan tes akhir. Skor yang ditampilkan adalah rerata, simpangan baku, dan jumlah siswa, data ini didapat dari hasil tes kemampuan komunikasi matematis sebanyak 6 soal. Gambar 1 menyajikan deskripsi data peningkatan kemampuan komunikasi matematis siswa.

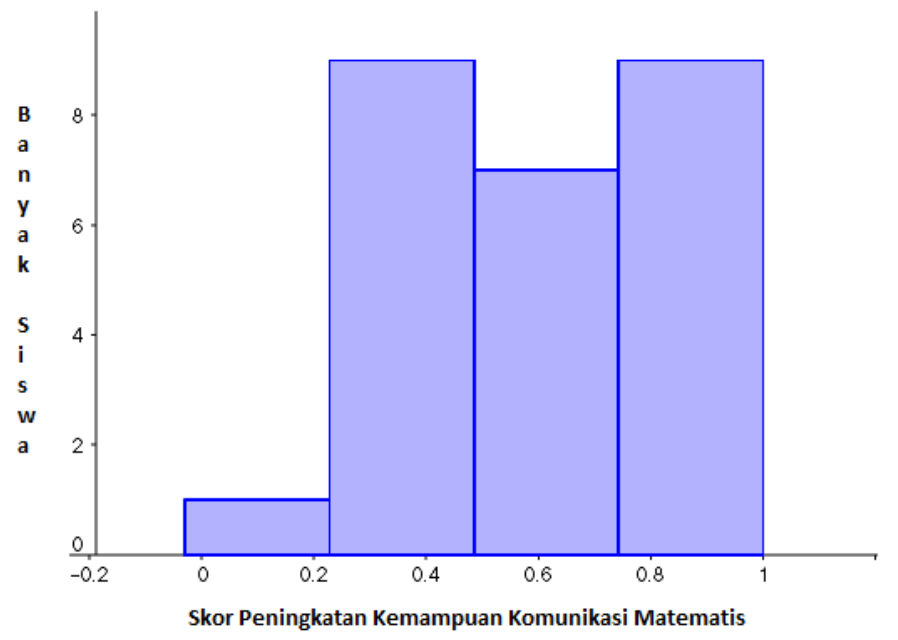

\section{Gambar 1. Skor Akhir Peningkatan Kemampuan Komunikasi Matematis}

Pada Gambar 1 terlihat peningkatan kemampuan komunikasi matematis siswa secara keseluruhan, siswa yang memperoleh peningkatan kemampuan dengan kategori tinggi $(>0,7)$ sebesar $56 \%$, siswa yang memperoleh peningkatan kemampuan dengan kategori sedang ( $0,3 \leq x \leq 0,7$ ) sebesar $34 \%$, sedangkan siswa yang memperoleh peningkatan kemampuan dengan kategori rendah $(<30)$ sebesar $9,4 \%$. Hal ini berarti bahwa perolehan peningkatan kemampuan komunikasi matematis siswa sebagian besar berada pada kategori tinggi.Hasil deskripsi Gambar 1 di atas diperkuat oleh hasil perhitungan output SPSS yang disajikan pada Table 1 berikut:

Tabel 1. Statistik Deskriptif Peningkatan Kemampuan Komunikasi Matematis

\begin{tabular}{ccccccc}
\hline & $\mathrm{N}$ & Min & Max & Mean & Std. Dev & Variance \\
\cline { 2 - 7 } Posttest & 32 & $-0,02$ & 1,00 & 0,66 & 0,27 & 0,07 \\
Valid N & 32 & & & & & \\
\hline
\end{tabular}


Tabel 1 memperlihatkan bahwa dari 32 siswa yang mendapat pembelajaran geometri berbasis GeoGebra terdapat seorang siswa yang skor peningkatannya bernilai negative, hal ini berarti siswa tersebut justru memiliki nilai tes akhir yang lebih kecil dari skor tes awalnya, namun secara rata-rata skor peningkatan kemampuan komunikasi matematis berada pada kategori sedang. Hasil statistik deskriptif ini memunjukkan bahwa kemampuan komunikasi matematis siswa mengalami peningkatan hasil lebih dari 50\% siswa pada kategori sedang. Untuk memperkuat temuan ini diperlukan uji lanjut menggunakan statistik inferensial.

\section{Analisisi Peningkatan Kemampuan Komunikasi Matematis siswa}

Untuk melakukan analisis inferensial perlu dilakukan terlebih dahulu uji normalitas, untuk menentukan uji statistik yang digunakan apakah parametrik atau non parametrik. Setelah itu dilakukan uji homogenitas untuk mengetahui kelayakan statistik inferensial pada data dua kelompok skor kemampuan komunikasi matematis. Uji normalitas dilakukan dengan menggunakan uji Kolmogorov-Smirnov. Rangkuman hasil perhitungan uji normalitas disajikan pada Tabel 2.

Tabel 2. Uji Normalitas Skor Normalized Gain Kemampuan Komunikasi Matematis Siswa

\begin{tabular}{cccccc}
\hline & \multicolumn{3}{c}{ Kolmogorov-Smirnov } & \multirow{2}{*}{ Kes. } & \multirow{2}{*}{ Ket. } \\
\cline { 2 - 4 } Gain & Statistic & df & Sig. & & \\
\cline { 2 - 4 } & 0,27 & 32 & 0,08 & Terima $\mathrm{H}_{0}$ & Normal \\
\hline
\end{tabular}

Dari Tabel 2 tampak bahwa skor uji Kolmogorov-Smirnov normalized gainkemampuan komunikasi matematis menghasilkan nilai sig. 0,08 yang lebih besar dari nilai $\alpha$ yang ditentukan sebesar 0,05. Hal ini berarti bahwa hipotesis nol kita tolak dan dapat disimpulkan skor normalized gainkemampuan komunikasi matematis berdistribusi normal.

Perhitungan selanjutnya adalah menguji homogenitas tiap kelompok skor kemampuan komunikasi matematis, uji homogenitas dilakukan dengan uji Levene. Untuk menguji homogenitas variansgain ternormalisai digunakan uji Levenemelalui SPSS 18 pada taraf signifikansi $\alpha=0,05$. Rangkuman perhitungan uji homogenitas disajikan pada Tabel $3 \mathrm{di}$ bawah ini.

Tabel 3. Uji Homogenitas Normalized Gain Kemampuan Komunikasi Matematis Siswa

\begin{tabular}{lccccc}
\hline & & $\begin{array}{c}\text { Levene } \\
\text { Statistic }\end{array}$ & Sig. & Kes. & Ket. \\
\hline $\begin{array}{l}\text { Normalized } \\
\text { Gain }\end{array}$ & $\begin{array}{l}\text { Based of } \\
\text { Mean }\end{array}$ & 0,86 & 0,36 & Terima Ho & Homogen \\
\hline
\end{tabular}

Tabel 3 menunjukkan bahwa nilai Sig. pada uji Levene pada kedua kelompok lebih besar dari $\alpha=0,05$, sehingga dapat disimpulkan bahwa skor peningkaatan komunikasi matematis siswa berasal dari populasi yang homogen. 
Setelah diketahui bahwa kelompok sampel penelitian berdistribusi normal dan homogen, selanjutnya dilakukan uji perbedaan rerata skor tes awal dan tes akhir kemampuan komunikasi matematis siswa. Untuk menguji perbedaan rerata skor tes awaldan tes akhir kemampuan komunikasi matematis siswabertujuan untuk membuktikan hipotesis penelitian, adapun hipotesis penelitian yang diajukan adalah:terdapat peningkatan kemampuan komunikasi matematis siswa yang signifikan dalam pembelajaran geometri berbasis GeoGebra.

Perhitungannya menggunakan SPSS 18 pada taraf signifikansi $\alpha=0,05$, rangkuman hasil perhitungan dari output SPSS ditunjukkan pada Tabel 4 di bawah ini.

\section{Tabel 4. Uji Perbedaaan Rerarta Peningkatan KemampuanKomunikasi Matematis Siswa}

\begin{tabular}{ccccc}
\hline $\begin{array}{c}\text { Aspek } \\
\text { Kemampuan }\end{array}$ & $\begin{array}{c}t \\
\text { hitung }\end{array}$ & $\begin{array}{c}\text { Asymp.Sig } \\
\text { (2-tailed) }\end{array}$ & $\begin{array}{c}\text { Asymp.Sig. } \\
\text { (1-tailed) }\end{array}$ & Kes. \\
\hline $\begin{array}{c}\text { Komunikasi } \\
\text { Matematis }\end{array}$ & 2,53 & 0,02 & 0,01 & Tolak Ho \\
\hline
\end{tabular}

Pada Tabel 4 tampak bahwa uji perbedaan rerata kemampuan komunikasi matematis siswa memperoleh nilai thitung $=2,53$ dengan Sig. $=0,002$ yang lebih kecil dari $\alpha=0,05$ sehingga HO ditolak. Artinya terdapat perbedaan pencapaian rerata skor kemampuan komunikasi matematis siswa secara signifikan pada siswa sebelum melaksanakan pembelajaran geometri berbasis GeoGebra dan sesudah pembelajaran geometri berbasis GeoGebra. Kesimpulannya pembelajaran geometri berbasis Geogebra mampu meningkatkan kemampuan komunikasi matematis siswa secara signifikan.

\section{PEMBAHASAN}

Penelitian ini menghasilkan beberapa temuan tentang peningkatan kemampuan komunikasi matematis siswa melalui penerapan pembelajaran geometris berbasis GeoGebra.

\section{Pembelajaran}

Berdasarkan hasil penelitian dapat dikemukakan bahwa siswa yang belajar matematika menggunakan pembelajaran berbasis GeoGebra mengalami peningkatan komunikasi matematis sebesar $90 \%$, hal tersebut menunjukkan bahwa setelah mendapat pembelajaran dengan menggunakan software interaktif seperti GeoGebra meningkat jauh lebih tinggi dibandingkan sebelum menggunakan media ajar software GeoGebra.

Terjadinya peningkatan kemampuan komunikasi matematis melalui pembelajaran menggunakan media ajar berbasis teknologi informasi disebabkan oleh perbedaan mendasar yang terjadi selama proses pembelajaran, pada kelompok siswa yang mendapatkan pembelajaran tanpa penggunaan teknologi informasi, siswa memperoleh pengetahuan tentang fakta, konsep dan prosedur hanya bersumber dari guru dan buku wajib. Kemudian pengetahuan tersebut digunakan untuk menjawab soal-soal yang bersifat mengulang dan mengaplikasikannya pada masalah rutin. Pada pembelajaran dengan menggunakan teknologi informasi siswa dibantu untuk lebih memahami pengetahuan berupa fakta, konsep dan prosedur yang disajikan dalam media ajar, karena media yang dibuat berbasis komputer menjadikan pembelajaran menjadi lebih informatif dan komunikatif. 
Media ajar elektronik yang interaktif memberikan keleluasaan bagi siswa untuk mengulang kembali serta mempelajarinya kapan saja dan di mana saja mereka berada tanpa harus bimbingan dari guru, karena dengan media ajar yang interaktif dapat menggantikan peran guru dalam memahami materi yang disajikan pada media ajar tersebut. Dengan demikian dapat dikemukakan bahwa dalam pembelajaran menggunakan bantuan komputer untuk memperoleh pengetahuan dan keterampilan lebih mudah diperoleh dan dipelajari ulang sehingga siswa lebih mudah menyelesaikan masalah yang disajikan. Lebih dari itu teknologi informasi pun dapat menampilkan visualisasi dari materi ajar yang diberikan secara cepat dan akurat. Visualisasi yang ditampilkan secara menarik, dapat digerakkan dan diubah bentuk serta ukurannya, memberi kesempatan kepada siswa untuk melakukan eksplorasi dan observasi dengan mudah. Eksplorasi sangat diperlukan ketika siswa berusaha memahami suatu konsep untuk membangun pengetahuannya.

Tidak seperti dalam pembelajaran biasa yang membuat siswa lebih cenderung bersikap pasif dalam menerima pembelajaran, suasana kelas dalam pembelajaran menggunakan komputer lebih bersifat dinamis. Siswa terlihat aktif berdiskusi dengan kelompoknya dalam upaya menyelesaikan masalah. Keaktifan siswa tersebut terjadi karena dalam pembelajaran tersebut tidak saja menekankan pada penguasaan materi tetapi juga keterampilan yang diperlukan dalam menyelesaikan masalah, pemerolehan pengetahuan dan bekerja sama. Hal ini merupakan salah satu karakteristik pembelajaran berbasis teknologi informasi yang berpusat pada siswa, karena dalam pembelajaran berbasis teknologi informasi siswa dituntut berusaha dengan sungguh-sungguh mempelajari materi yang disajikan, mengidentifikasi apa yang dipelajari, mencari penyelesaian masalah dan bagaimana cara terbaik untuk menyelesaikan masalah. Siswa perlu mengetahui bagaimana mengidentifikasi informasi yang penting yang perlu mereka dipelajari, mencari dan memperoleh informasi, serta bagaimana menggunakan informasi tersebut untuk menyelesaikan masalah.

Aspek penunjang lain dalam pembelajaran menggunakan media ajar elektronik interaktif adalah siswa dapat berinteraksi dengan sangat baik diantara siswa dengan fasilitas yang diberikan. Dalam interaksi tersebut mereka dapat saling berdiskusi tentang materi yang disajikan untuk menemukan solusi masalah yang disajikan. Jika terdapat suatu masalah yang tidak dapat diselesaikan dalam diskusi, guru akan mengulas masalah tersebut. Hal ini sangat berbeda dengan pembelajaran biasa yang diterapkan di sekolah, setiap siswa bekerja secara individu sehingga menimbulkan persaingan di antara mereka. Sebaliknya pada pembelajaran menggunakan media ajar elektronik interaktif berupa software GeoGebra, muncul rasa tanggung jawab kepada kelompok akibatnya setiap individu ingin membantu anggotanya kelompok lainya dan setiap siswa memberi kontribusi kepada pencapaian tujuan kelompok. Kemampuan interpersonal turut berkembang karena dalam kelompok terlibat komunikasi aktif, kepemimpinan, pengambilan keputusan, dan refleksi tentang kemajuan yang berhasil dicapai kelompok.

Komunikasi yang terjadi pada siswa yang mendapat pembelajaran menggunakan media ajar elektronik interaktif berupa software GeoGebra semakin efektif karena fasilitas teknologi komputer. Media ajar elektronik interaktif mempunyai interface yang menarik dan kemampuan visualisasi yang cepat dan tepat. Siswa mempunyai keingintahuan yang besar ketika mengamati tampilan materi tersebut sehingga secara spontan mereka bertanya jawab, memprediksi, berargumentasi sesama mereka dan juga terhadap guru. Teknologi sebagai alat kognitif yang dipergunakan untuk mencari informasi, membuat model dan menyajikan solusi meningkatkan kolaborasi, berbagi ide, motivasi dan perilaku sosial. 
Selain itu belajar dengan fasilitas komputer secara berkelompok memberi siswa perasaan nyaman karena mereka tidak berinteraksi langsung dengan guru. Ketika mereka berinteraksi langsung dengan guru terdapat perasaan segan karena takut salah dan takut ketidakmampuannya diketahui oleh teman. Pembelajaran menggunakan fasilitas komputer dan dilakukan secara berkelompok menunjukkan hasil yang berbeda, mereka lebih berani berpendapat, mengembangkan pendapat teman dan berargumentasi untuk menguji kebenaran suatu pendapat. Belajar secara berkelompok menyebabkan motivasi belajar meningkat dan berkurangnya kecemasan siswa.

Belajar mengunakan media ajar elektronik interaktif berupa software GeoGebra memungkinkan siswa untuk menyelesaikan masalah yang berhubungan dengan masalahmasalah yang sering mereka temui dalam kehidupan sehari-hari lebih banyak daripada yang dikerjakan pada kelas pembelajaran biasa. Selain itu interaksi dalam memecahkan masalah lebih mendekati kenyataan tentang bagaimana siswa menyelesaikan masalah dalam kehidupan sehari-hari yang berhubungan dengan matematika. Hal ini sangat diperlukan ketika siswa berada di luar lingkungan sekolah seperti di lingkungan masyarakat dan lingkungan tempat bekerja nantinya.

\section{Kemampuan Komunikasi Matematis Siswa}

Kemampuan berpikir matematis yang diukur dalam penelitian ini adalah kemampuan komunikasi matematis. Berdasarkan temuan penelitian, dapat disimpulkan bahwa terdapat peningkatan yang signifikan pada kemampuan komunikasi matematis siswa yang mendapat pembelajaran menggunakan pembelajaran geometri berbasis GeoGebra. Peningkatan tersebut disebabkan oleh aktivitas siswa dalam proses menyelesaikan masalah. Selain itu penggunaan teknologi komputer dapat lebih memudahkan siswa bereksplorasi untuk menentukan pola, membuat kesimpulan dan berkomunikasi intensif dengan sesama peserta belajar lain. Hal ini sesuai dengan temuan Stoney dan Oliver, mereka menyimpulkan bahwa teknologi komputer dapat melibatkan siswa secara mental dan mengkondisikan siswa untuk berpikir ketingkat yang lebih tinggi.

Pada siswa yang mengalami pembelajaran menggunakan pembelajaran menggunakan pembelajaran geometri berbasis GeoGebra jika ditinjau dari banyak siswa yang mendapat skor tes akhir kemampuan komunikasi melebihi nilai Kriteria Ketuntasan Minimal (KKM) yang ditentukan sebesar 78 maka dapat disimpulkan 87\% siswa berhasil melebihi nilai KKM mata pelajaran matematika yang telah ditentukan. Fenomena ini menunjukkan bahwa pembelajaran menggunakan pembelajaran menggunakan pembelajaran geometri berbasis GeoGebra sangat cocok digunakan untuk peningkatan kemampuan komunikasi matematis. Hal ini sesuai dengan temuan Koohang dan Durante yang menyimpulkan bahwa siswa yang belajar dilingkungan berbantuan komputer akan meningkatkan motivasi yang tinggi untuk memajukan diri sendiri, memiliki kedisiplinan mandiri yang tinggi, dan manajemen waktu yang baik dalam belajar sehingga hasil belajar yang didapat meningkat secara signifikan. 
Peningkatan kemampuan komunikasi matematis siswa ditunjukkan dengan kemampuan siswa menjelaskan suatu persoalan secara tertulis dalam bentuk gambar; kemampuan siswa menyatakan suatu persoalan secara tertulis dalam bentuk model matematis; kemampuan menjelaskan ide atau situasi dari suatu gambar yang diberikan dengan kata-kata sendiri dalam bentuk tulisan. Sebagai ilustrasi, untuk menjawab pertanyaan tentang table distribusi frekuensi dan sebaran warga yang yang terserang penyakit cacar, yang harus dipahami siswa adalah cara mengkomunikasikan tabel tesebut dalam notasi dan bahasa matematis. Siswa harus paham terlebih dahulu bagaimana dan apa maksud dari tabel yang diberikan, baru setelah itu siswa dapat menjawab bagaimana table distribusi frekuensi dan data sebarannya. Di sini kemampuan komunikasi matematis siswa digunakan, siswa diharapkan mampu menjelaskan ide atau situasi dari suatu gambar yang diberikan dengan kata-kata sendiri dalam bentuk tulisan.

Peningkatan kemampuan komunikasi matematis disebabkan oleh karakteristik pembelajaran menggunakan pembelajaran geometri berbasis GeoGebra, pembelajaran dengan media seperti ini mempunyai keunggulan dalam hal sumber daya belajar (resources), kebiasaan belajar siswa yang sudah terbiasa belajar dengan cara mengintegrasikan konsepkonsep matematika dengan pengamalan ajaran Islam dalam kehidupan sehari-hari. Selain itu temuan penelitian menunjukkan bahwa peningkatan kemampuan komunikasi matematis melalui pembelajaran geometri berbasis GeoGebra tidak tergantung kepada kemampuan awal siswa. Artinya siswa dengan kemampuan awal berapapun dapat ditingkatkan kemampuan komunikasi matematisnya. Keadaan ini tidak terlepas dari unsur sumber daya yang tak terbatas. Sumber daya tersebut memudahkan siswa memahami konsep, bertanya, bereksplorasi dan berdiskusi tanpa keterbatasan waktu dan tempat. Temuan ini sesuai dengan Walmsley yang menyatakan fleksibilitas dan aksebilitas, baik dalam hal waktu dan tempat serta aksesibilitas sumber daya belajar dalam pembelajaran geometri berbasis GeoGebra membuat siswa nyaman untuk belajar pada saat kapanpun mereka mengiginkannya.

\section{KESIMPULAN}

Berdasarkan analisis data dan pembahasan yang telah dipaparkan pada bab sebelumnya, diperoleh beberapa kesimpulan sebagai berikut:

Pembelajaran geometri berbasis GeoGebra pada proses pembelajaran terbukti secara signifikan dapat meningkatkan kemampuan komunikasi matematis siswa, selaian itu sikap kritis dan kreatif selama pembelajaran ditunjukkan siswa.

Peningkatan kemampuan komunikasi matematis siswa yang mendapat pembelajaran geometri berbasis GeoGebra berada pada kategori sedang. Hal ini menunjukkan bahwa siswa telah mengalami peningkatan kemampuan komunikasi matematis lebih baik dibandingkan hasil sebelumnya. 


\section{DAFTAR PUSTAKA}

Abdussakir. (2009). Pembelajaran Geometri dan Teori Van Hiele. [Online]. Tersedia: http://abdussakir.wordpress.com. (26 Januari 2011).

Asikin, M. (2002). Menumbuhkan Kemampuan Komunikasi Matematika melalui Pembelajaran Matematika Realistik. (Prosiding Konferensi Nasional Matematika XI).

Astuti, R. (2009). Meningkatkan Kemampuan Komunikasi Matematik dan Kemandirian Belajar Matematika Siswa Melalui Model Reciprocal Teaching Dengan Pendekatan Metakognitif. Tesis pada SPs UPI: Tidak diterbitkan.

Dasari, D. (2009). Kemampuan Penalaran Statistis Mahasiswa dan Upaya Meningkatkannya Melalui Pembelajaran Model PACE. (Prosiding Seminar Nasional Matematikan dan Pendidikan Matematika UPI).

Depdiknas. (2006). Pengembangan Bahan Ujian dan Analisis Hasil Ujian: Materi Presentasi Sosialisasi KTSP. Jakarta: Departemen Pendidikan Nasional.

Jiang, Z. (2008). Explorations and Reasoning in the Dynamic Geometry Environment. [Online]. Tersedia: http://atcm.mathandtech.org/. (12 Oktober 2010).

Jihad, A. (2008). Pengembangan Kurikulum Matematika (Tinjauan Teoritis dan Historis). Yogyakarta: Multi Pressindo.

Kusumah, Y. S. (2008). Konsep, Pengembangan, dan Implementasi Komputer-Based Learning dalam Peningkatan Kemampuan High-Order Mathematical Thinking. Makalah disajikan dalam Pengukuhan Guru Besar Pendidikan Matematika FMIPA UPI.

Kesumawati, N. (2010). Peningkatan Kemampuan Pemahaman, Pemecahan Masalah, dan Disposisi Matematis Siswa SMP Melalui Pendekatan Matematika Realistik. Disertasi pada SPs UPI: Tidak diterbitkan.

Mulyasa. (2008). Implementasi Kurikulum Tingkat Satuan Pendidikan, Kemandirian Guru dan Kepala Sekolah. Jakarta: Bumi Aksara.

Noer, S.H. (2010). Peningkatan Kemampuan Berfikir Kritis, Kreatif, dan Reflektif (K2R) Matematis Siswa SMP Melalui Pembelajaran Berbasis Masalah. Disertasi pada SPs UPI: Tidak diterbitkan.

Nurhasanah, F. (2010). Abstraksi Siswa SMP Dalam Belajar Geometri Melalui Penerapan Model Van Hiele dan Geometers' Sketchpad. Tesis pada SPs UPI: Tidak diterbitkan.

Nur'aeni, E. (2010). Pengembangan Kemampuan Pemahaman dan Komunikasi Matematis Siswa Sekolah Dasar Melalui Pembelajaran Geometri Berbasis Teori Van Hiele. Disertasi pada SPs UPI: Tidak diterbitkan.

Rahman, R. (2010). Pengaruh Pembelajaran Berbantuan Geogebra Terhadap Kemampuan Berpikir Kreatif dan Self-Concept Siswa. Tesis pada SPs UPI: Tidak diterbitkan.

Reis, Z.A dan Gulsecen, F. (2010). The Effect Of GeoGebra Use In Mathematics Education: A Case Study On Integers In Turkey. Paper presented at Geogebra National Annual, New York. [Online]. Tersedia: www.geogebra.org. (2 Oktober 2010).

Rusmini. (2007). Meningkatkan Kemampuan Penalaran dan Komunikasi Matematis Siswa SMP Melalui Pendekatan Pembelajaran Kontekstual Berbantuan Program Cabri Geometri. Tesis pada SPs UPI: Tidak diterbitkan.

Siregar, N. (2009). Studi Perbandingan Kemampuan Penalaran Matematik Siswa Madrasah Tsanawiyah Pada Kelas yang Belajar Geometri Berbantuan Geometer's Sketchpad Dengan Siswa yang Belajar Geometri Tanpa Geometer's Sketchpad. Tesis pada SPs UPI: Tidak diterbitkan. 
allobar: Jurnat Pondidillon Matemothlo
P-ISSN $2086-5872$
e-ISSN $2540-7562$

Siregar, N. (2011). Pembelajaran Geometri Melalui Model PACE Berbantuan GEOGEBRA Sebagai Upaya Meningkatkan Kemampuan Penalaran dan Komunikasi Matematis Siswa SMA (Doctoral dissertation, Tesis pada SPs UPI: Tidak diterbitkan)

Sudjana. (2005). Metode Statistika. Bandung: Tarsito.

Sumarmo, U. (2010). Berfikir dan Disposisi Matematik: Apa, Mengapa, dan Bagaimana Dikembangkan pada Peserta Didik. FPMIPA UPI. Tersedia.

Ulya, N. (2007). Upaya Meningkatkan Kemampuan Penalaran dan Komunikasi Matematik Siswa Smp/Mts Melalui Pembelajaran Kooperatif Tipe Teams-GamesTournaments (TGT). Tesis pada SPs UPI: Tidak diterbitkan.

Wahyudin. (2008). Pembelajaran Dan Model-Model Pembelajaran (Pelengkap Untuk Meningkatkan Kompetensi Pedagogis Para Guru dan Calon Guru Profesional). Bandung.

Wardhani, S. (2008). Analisis SI dan SKL Mata Pelajaran Matematika SMP/MTs untuk Optimalisasi Tujuan Mata Pelajaran Matematika. Pusat Pengembangan Dan Pemberdayaan Pendidik dan Tenaga Kependidikan Matematika. Yogyakarta.

Whidiarso, W. (2007). Uji Hipotesis Komparatif. [online]. Tersedia: http://elisa.ugm.ac.id/files/wahyu_psy/maaio0d2/Membaca_t-tes.pdf (27 Juni 2009). 2009). 